\title{
Review
}

\section{Antibiotic usage and resistance in Mexico: an update after a decade of change}

\author{
Carlos F Amábile-Cuevas ${ }^{1}$ \\ ${ }^{1}$ Fundación Lusara, Mexico City, Mexico
}

\begin{abstract}
Ten years ago, a review on the status of resistance in Mexico was bleak: with antibiotics freely sold over the counter and poor regulation of generic drugs, among other conditions, resistance among relevant pathogens often ranked top, either among Latin American countries, or even worldwide. Since then, there have been some regulatory changes, along a decline in antibiotics usage: antibiotics are (supposedly) no longer sold without prescription, generic drugs (supposedly) have to demonstrate bioequivalence, and antibiotic usage has drop, from about 13 defined daily doses per 1,000 inhabitants per day, to 7 . While these changes may sound encouraging, an analysis show that regulatory changes are incomplete at best, and usage decline may be the consequence of factors such as growing poverty. The assessment of resistance continues to be haphazard, without an organized network of laboratories providing a coherent picture. However, judging from a few nationwide reports, it appears that resistance among some nosocomial pathogens (MRSA, enterococci, Pseudomonas aeruginosa) is declining, as it is among pneumococci and enteropathogens; but it is rising among community-acquired, uropathogenic Escherichia coli. Resistance to colistin is slowly increasing; and worrisome resistance determinants, such as bla $\mathrm{NDM}_{-1}$ and $m c r-1$, appeared in Mexico shortly after their first report elsewhere. After four years from the United Nations General Assembly high-level meeting on antibiotic resistance, Mexico is yet to deploy the basic measures to assess and control antibiotic resistance. As such, and despite the regulatory changes, the 2010-2020 period looks like a "lost decade".
\end{abstract}

Key words: Antibiotic resistance; Mexico; self-prescription; generic drugs; antibiotic usage.

J Infect Dev Ctries 2021; 15(4):442-449. doi:10.3855/jidc.13467

(Received 13 July 2020 - Accepted 30 November 2020)

Copyright (C) 2021 Amábile-Cuevas et al. This is an open-access article distributed under the Creative Commons Attribution License, which permits unrestricted use, distribution, and reproduction in any medium, provided the original work is properly cited.

\section{Introduction}

Ten years ago, I wrote a brief review on the status of antibiotic resistance in Mexico [1], including some actual data on the prevalence of resistance among relevant pathogens, but also an overview of the underlying causes of the problem. Back then, Mexico had reportedly the highest rates of penicillin-resistance among pneumococci in Latin America; and the highest worldwide rates of carbapenem-resistance among Pseudomonas aeruginosa. Antibiotics were sold freely at drugstores, and there was a very confuse and lax regulation for generic drugs. There was almost no data of public knowledge on the use of antibiotics. Parenteral polymyxins were not available, making carbapenems the drugs of "last resort" against infections caused by multi-resistant organisms. Many of the issues stated before have changed along these decade, making it interesting to review again how things are now, and what impact, if any, such changes have had in terms of antibiotic resistance prevalence.

Mexico is a middle-income, "developing" country. Data from Wikipedia, just to provide a very coarse overview of the socio-economic characteristics of the country, include: (a) it is the tenth most populated country in the world, with about 126 million inhabitants (79\% living in cities); (b) it is the fifteenth largest economy in nominal terms (eleventh in purchasing power parity); (c) it is said to has the second highest degree of economic disparity in the Americas, between the extremely poor and the extremely rich, only after Chile; but has a Gini index of 43.4, below that of Bolivia, Brazil, Chile, Colombia, Costa Rica, Guatemala, Haiti, Honduras, Nicaragua, Panama, Paraguay and Venezuela, in alphabetical order (although other sources state a Gini index of 50.3; [2]); (d) "while less than $2 \%$ of Mexico's population lives below the international poverty line set by the World Bank, as of 2013, Mexico's government estimates that $33 \%$ of Mexico's population lives in moderate poverty and $9 \%$ lives in extreme poverty, which leads to $42 \%$ of Mexico's total population living below the national poverty line"; and (e) has 21 physicians per 10,000 inhabitants, below Cuba (67.2), Argentina (38.6), and Uruguay (37.4), among Latin American countries. 
Some further data on specific healthcare issues: (a) about $18 \%$ of the total population lacks access to health services [3]; (b) about $48 \%$ of the total expenditure on health is private; (c) a staggering $41 \%$ of the total expenditure in health is out-of-pocket payment (with $2 \%$ of households experiencing catastrophic health expenditures); and (d) the total health expenditure is $5.8 \%$ of the GDP [2].

\section{Antibiotic usage}

At about the same time that the JIDC paper came out, an analysis on the use of antibiotics in Latin American countries, including Mexico, was published; it included data up to 2007 [4]. Mexico was, between 1997 and 2004, the leading country in antibiotic clinical use, at about 14-16 defined daily doses per 1000 inhabitants per day (DDD/TID); by 2007, Mexico was down to the fourth place, with 13.26 DDD/TID, below Argentina, Venezuela and Peru.

Further papers documented the trend towards reduction of antibiotic usage: in 2010 (three years after the last data available in ref. 4), antibiotic usage "expressed in standard units (i.e., pill, capsule, or ampoule) per person", was in the 8-13 range, with a 6.25 to -4.00 compound annual growth rate [5]; by 2015, antibiotic consumption, in DDD/TID, was around 7 , well below most other Latin American countries reported [6].

The continuous reduction in antibiotic usage, noticed since the Wirtz et al. paper [4], could be taken as a promising trend towards rational prescription practices. But it can also be the mere effect of an also continuous decay of income: in the same paper, the dramatic drop in antibiotic usage in Argentina, from 14.37 DDD/TID in 1997, to around 8 in 2002, coincided with the deep financial crisis that country suffered during the same period of time. As the Argentinian economy recovered, also did antibiotic usage, reaching 16.64 DDD/TID in 2007, and further increased in 2015 [6]. In that sense, "the Mexican economy has experienced a long-term decrease of its growth rate during the last three decades" [2]. Reduction on antibiotic usage because of poverty might not be as positive a trend as reduction due to improved prescription practices.

\section{Self-prescription}

Shortly after the publication of the 2010 assessment, the purchase of antibiotics at drugstores without a written medical prescription was banned. The head of the Commission for Health Risks Prevention (Cofepris, that includes functions equivalent to those of the Food and Drug Administration [FDA] in the USA, or the European Medicines Agency [EMeA] in EU) wrote about the measure in a Mexican newspaper: "According to studies by the WHO and the Mexican Institute of Public Health, people that take antibiotics become immune and resistant towards bacteria they did not have" [7] (this is not a translation error). During the weeks after the measure was announced, some professional associations published their support to it in newspapers, stating that it was also necessary to start an educational program both, for physicians and for the public, to optimize the use of antibiotics. Such a program was never even considered [8]. Today, while it is supposedly necessary to produce a medical prescription to buy an antibiotic at a drug store, anybody can print one with fake data of a physician, and get the drug; or, when ordering by phone for homedelivery, only the registry number of the physician is required, and any number of the adequate digit length would do. A side-effect of this defective regulatory framework is that it would be now impossible to assess the current prevalence of self-prescription of antibiotics: by law, it is now $0 \%$.

Little is known about the impact of the sales restriction of antibiotics. The number of DDD/TID between the second and the fourth quarter of year 2010 was about the same, keeping with the decreasing trend previously discussed; and the average of the seven quarters before and after the prohibition of OTC sales of antibiotics mostly affected penicillins (from 3.5 DDD/TID, to 2.3), tetracyclines (from 0.74 to 0.57 ) and sulfonamides (from 1.06 to 0.69 ); but not affecting macrolides (from 0.97 to 0.87 ), quinolones (from 1.16 to 1.06 ) or other kinds of antibiotics (from 1.44 to 1.45 ) [9]. This tend to confirm a trend anecdotically reported by marketing employees of local pharmaceutical companies: that while total sales of antibiotics were slightly diminished by the restriction, it rather caused a change towards newer, wider-spectrum antibiotics, which physicians like the most, instead of the older, cheaper options preferred by people self-prescribing antibiotics. Should this be the case, the new regulation would have a negative impact upon resistance prevalences. This seems to be confirmed by the data on resistance: while resistance among some nosocomial pathogens is diminishing -and antibiotic usage in hospitals has always been, by definition, medically prescribed; resistance among community-acquired pathogens, such as uropathogenic E. coli, appears to be rising dramatically, especially towards fluoroquinolones and cephalosporins (see below). The expected impact of banning OTC sales of antibiotics 
should have been precisely upon community-acquired organisms.

\section{Generic antibiotics}

The regulation of generic drugs in Mexico evolved erratically during the last 35 years: drug patents were not respected until the signature of the North America Free Trade Agreement (1994); then, several guidelines on bioequivalence and generics were issued, but without actual enforcement. By the time the 2010 review was written, there still were several "varieties" of drugs, aside from the "innovators" (i.e., the ones that hold or held the patent): "copies" and "similars" were the most used names. The entanglement of political interests in this issue was briefly discussed in that paper. It was only until 2013 that all oral generic drugs in Mexico had to demonstrate bioequivalence to be approved for sale. For that purpose, private companies (called "authorized third parties") hired by generic manufacturers should conduct the typical bioequivalence trials (about a dozen "professional" volunteers, a single-dose pharmacokinetic profile, an $80-125 \%$ tolerance for $\mathrm{C}_{\max }$ and AUC). Aside from the host of anecdotal, unproven stories about the conflict of interest and corruption that are rife within this industry, there is little evidence on the quality of generic drugs in Mexico. Nevertheless, it is important to recall that there are many published papers documenting the different, mostly diminished activity of generic antibiotics, despite having proven bioequivalence; Colombian pharmacologist $\mathrm{O}$. Vesga is a main author in the subject. Vesga's group has at least two papers on the impact of generics upon bacterial resistance: one on ciprofloxacin, showing that resistant $P$. aeruginosa emerged about the same when under innovator or generic exposure [10]; and another showing a 20-fold increase in the rate of resistant vs. susceptible Escherichia coli, comparing generic and innovator piperacillin-tazobactam [11]. Another paper showed a $200 \%$ increase in ciprofloxacin resistance after the introduction of generics, which the authors attributed to increased usage due to diminished price [12].

The approval of generic drugs in Mexico was boosted, especially during the 2012-2018 administration, when the Cofepris granted fast-track approval to generic drugs that were already accepted by the FDA. Then, it is perhaps worth to recall the episode of Ranbaxy, the generic manufacturer that, on May 13, 2013, "pleaded guilty to seven federal criminal counts of selling adulterated drugs with intent to defraud, failing to report that its drugs didn't meet specifications, and making intentionally alse statements to the [US] government". This large drug fraud was mainly caused because the FDA relies on data provided by the companies themselves. "We depend on that information to the truthful", Gary Buehler, who headed the FDA's office of generic drugs for 10 years, said in December 2009. The approval system "requires the ethical behavior of the applicant", he said. Otherwise, "the whole house of cards will fall down". [13]. Hence, generics in Mexico are quickly approved if they were previously accepted by the FDA, which in turn, relies on data provided by the generic's manufacturer. Not surprisingly, there are many anecdotic reports of clinical failure of generic drugs in Mexico; unfortunately, there is no hard evidence of this.

\section{Agricultural use of antibiotics}

If data on clinical use of antibiotics is scarce, much less is known about the agricultural use in the country. While a 2007 Federal Law of Animal Health restricts the use of antibiotics in animal feed (with significant exceptions) and requires a prescription for antibiotic use in food animals [14], a report projects that, by 2030 , Mexico will be amongst the five countries with largest shares of global antimicrobial consumption for food animals, with $2 \%$ of 105,596 tons, after China, US, Brazil and India [15].

While adding antibiotics as "growth promoters" to food animals is the main cause of concern regarding agricultural usage, there are other, perhaps just as dangerous forms of abuse. Streptomycin, oxytetracycline and gentamicin are used in Mexico to control bacterial infections of apples, pears and peaches. While this only amounts to $0.12 \%$ of the antibiotics used agriculturally worldwide, these drugs are sprayed directly to the environment, where they can affect soil and water bacteria, known to carry ancient resistance genes [16].

\section{Corruption}

Corruption in Mexico has been a permanent scourge; but in 2015, Collignon et al. [17] reported on the contribution of corruption upon the growth of antibiotic resistance. According to that paper, corruption correlates more closely to antibiotic resistance, than antibiotic usage, among European countries. By 2017, according to the Corruption Perceptions Index, Mexico ranked 135 out of 180 countries

(en.wikipedia.org/wiki/Corruption_in_Mexico), a position that has been in decline especially since 2015 (en.wikipedia.org/wiki/Corruption_Perceptions_Index) . It is therefore not a surprise that resistance of some 
pathogens (e.g., pneumococci, P. aeruginosa) is amongst the highest in the region (in Latin America, only Guatemala, Nicaragua and Venezuela rank below Mexico in corruption control), or even in the entire world. It is still too early to assess if a dramatic government change that occurred in Mexico in 2018 would have an actual impact on the levels of corruption, not to say on the levels of antibiotic resistance.

\section{Resistance}

Despite the 10-year distance, Mexico still lacks a national network for measuring antibiotic resistance. Therefore, available data is a patchwork of local reports without uniform methodology, rather than a coherent national picture. In order to try a comparison between the situation reported ten years ago and the current one, an updated table was assembled (Table 1), using data from that review, and from a recent, unique multi-center survey. This table must be read with some cautionary notes: (a) as stated before, data came from very different settings and methodologies; (b) there are stark differences between regions (and between hospitals within the same region), hence an "average" is not necessarily a good indicator; and (c) hospitals from large, richer cities are over-represented, with very few data from smaller cities and rural areas. Nevertheless, it seems that resistance among nosocomial isolates diminished during the 2010-2020 period, with the exception of extended-spectrum beta-lactamase (ESBL) -producing Klebsiella spp. and piperacillin/tazobactam resistance among Acinetobacter spp.; resistance in pneumococci and enteropathogens also seem to be diminishing, while resistance among uropathogenic E. coli increased substantially, especially towards fluoroquinolones and third-generation cephalosporins. Again, these results must be read with caution. For instance, data from 2010 came from nearly 1,000 isolates from communityacquired urinary infections, mostly in young women at Mexico City [18]; but even amongst a few (119) earlier

Table 1. Antibiotic resistance in Mexico at a glance: 2010 to 2020.

\begin{tabular}{|c|c|c|c|}
\hline Organism & Antibiotic & Resistance $2010(\%)^{a}$ & Resistance $2020(\%)^{b}$ \\
\hline \multicolumn{4}{|c|}{ community-acquired } \\
\hline \multirow[t]{2}{*}{ S. pneumoniae } & penicillin & $70^{c}$ & $36.8^{\mathrm{c}, \mathrm{d}}$ \\
\hline & clarithromycin & 49 & $37.2^{\mathrm{d}}$ \\
\hline \multirow[t]{4}{*}{ Salmonella spp. } & ampicillin & 66 & $12-28$ \\
\hline & co-trimoxazole & 66 & $13-17$ \\
\hline & chloramphenicol & 20 & \\
\hline & ceftriaxone & 12 & \\
\hline \multirow[t]{3}{*}{ Shigella spp. } & ampicillin & 81 & 25 \\
\hline & co-trimoxazole & 81 & 38 \\
\hline & chloramphenicol & 11 & \\
\hline \multirow[t]{4}{*}{ E. coli (uropathogenic) } & ampicillin & 74 & 82 \\
\hline & co-trimoxazole & 60 & 62 \\
\hline & ciprofloxacin & 33 & 62 \\
\hline & ceftazidime & 8 & $55^{\mathrm{e}}$ \\
\hline \multirow[t]{2}{*}{ M. tuberculosis } & MDR & 17 & $20.6^{\mathrm{f}}$ \\
\hline & & & \\
\hline \multirow[t]{2}{*}{ Klebsiella spp. } & ESBL & 28 & $55.5^{\mathrm{g}}$ \\
\hline & imipenem & & $6-10$ \\
\hline S. aureus & methicillin & 48 & $25^{\mathrm{h}}$ \\
\hline E. faecium & vancomycin & 33 & 21 \\
\hline \multirow[t]{5}{*}{ P. aeruginosa } & amikacin & 20 & 17 \\
\hline & ceftazidime & 39 & \\
\hline & imipenem & 43 & 30 \\
\hline & levofloxacin & 40 & 22 \\
\hline & piperacillin/ tazobactam & 28 & 15 \\
\hline \multirow[t]{5}{*}{ Acinetobacter spp. } & amikacin & 40 & \\
\hline & ceftazidime & 72 & \\
\hline & levofloxacin & 51 & \\
\hline & piperacillin/ tazobactam & 51 & 74 \\
\hline & imipenem & & $53-86$ \\
\hline
\end{tabular}

a. data from ref. 1; b. data from ref. 27, except where stated otherwise; c. non-susceptible: resistant + intermediate; d. data from ref. 45: 78 isolates from 20082015; e. 2020 values are for cefoxitin, as ceftazidime was not tested; f. data from ref. 46; g. considered as ESBL-producers because of aztreonam resistance; h. considered as MRSA because of cefoxitin resistance. 
isolates, also from Mexico City outpatients, ciprofloxacin resistance was reported as high as $55.5 \%$ [19]; by 2016, amongst $48 \mathrm{E}$. coli isolates from recurrent cystitis and prostatitis, $80 \%$ were ciprofloxacin-resistant [20]; and amongst 582 uropathogenic E. coli isolates (2007-2017) from a private clinic at a central-Mexico state, $74.1 \%$ were non-susceptible to ampicillin, $57.7 \%$ to ciprofloxacin, 56.2 to ceftriaxone, $56.4 \%$ to co-trimoxazole, and $10.7 \%$ to nitrofurantoin [21]. On the other hand, while most surveys point towards high prevalence of ciprofloxacin, ceftazidime and imipenem resistance among nosocomial $P$. aeruginosa, a few (92) recent isolates from public hospitals at a northern Mexican state found it only to be 2-9\% (although this report also found only $10-20 \%$ resistance towards aminopenicillins, a group of antibiotics $P$. aeruginosa is intrinsically resistant to) [22].

As can be seen, and because of the lack of standard operating procedures, data on resistance in Mexico is unreliable; even the same groups can report very different figures within the same time framework. For instance, two papers sharing main authors, one from 2012 and the other from 2015, report, respectively: susceptibility of Acinetobacter spp. towards amikacin, $22.1 \%$ and $49.4 \%$; levofloxacin, $18.7 \%$ and $41.3 \%$; meropenem, $\quad 52.3 \%$ and $66.2 \%$; piperacillin/tazobactam, $16.3 \%$ and $43.3 \%$; and susceptibility of $P$. aeruginosa towards levofloxacin, $74.2 \%$ and $58.7 \%$; meropenem, $76.4 \%$ and $56 \%$; piperacillin/tazobactam, $68.8 \%$ and $57.8 \%$. In contrast, susceptibility rates variation among Klebsiella spp., and E. coli between both studies was within $10 \%$ [23, 24]. It is therefore too difficult to draw conclusions from published data, even coming from prestigious authors and journals.

Just about the time the previous review was published, colistin returned to the Mexican market, after nearly 40 years of absence. Shortly before the reintroduction, colistin was sold in the black market outside large public hospitals, as a last resort antibiotic useful for fighting infections caused by some carbapenem-resistant gram-negatives. Data on colistin resistance is slowly emerging: by $2010,0.2 \%$ of E. coli, $0.4 \%$ of Klebsiella spp., and 1.5\% Acinetobacter spp.; no colistin-resistant $P$. aeruginosa was detected [24]. In a Latin American study of multi-resistant gramnegatives isolated between 2015 and 2017, colistin resistance was detected in $1.5 \%$ of the 603 Mexican ESBL-producing enterics, $18.8 \%$ of the 32 carbapenemase-producing enterics, $1.9 \%$ of the $524 P$. aeruginosa, and $3.6 \%$ of the 169 multi-resistant $P$. aeruginosa [25]. In specific clinical settings, colistin resistance could be much higher: 13 out of 49 (26.5\%) of the $P$. aeruginosa isolated from Mexican children with cystic fibrosis were resistant to colistin [26].

Among the gram-positives, vancomycin-resistance was not detected in $S$. aureus; but linezolid resistance was found in 0.7 of $S$. aureus (although $1.8 \%$ were resistant to teicoplanin), 2.4\% of Enterococcus faecalis and $7.3 \%$ of E. faecium [27].

\section{New resistance crises}

During these 10 years, a number of particularly concerning resistance traits were discovered worldwide. Shortly before the 2010 review, the New Delhi Metallo-beta-lactamase (NDM) was first reported [28]; metallo-beta-lactamases were by no means new, but their presence in enteric bacteria, and their dissemination through medical tourism added to a new level of threat. NDM-1 was rapidly reported worldwide, followed by several variants (up to NDM-28). The first report of a Mexican clinical isolate (Providencia rettgeri) harboring the bla $a_{\mathrm{NDM}-1}$ gene was published in 2013 [29]; two years later, an outbreak caused by several Enterobacteriaceae producing NDM-1 was reported from a hospital in Mexico City [30].

Another especially grave developing was the detection of a plasmid-borne colistin resistance determinant, $m c r-1$, first reported in 2016 in China [31]. Since then, a number of variants $(m c r-2$ thru $m c r-10)$ have been reported worldwide. The possibility of horizontal transfer of colistin resistance, and of linkage of the colistin-resistance determinant to genes mediating resistance to other antibiotics, is especially worrisome. The first report of an isolate carrying $\mathrm{mcr}-1$ in Mexico was published in 2018: an E. coli strain from a swine farm [32]. A year later, an E. coli isolate from a fecal sample of a hospitalized child was also found to carry the $m c r-1$ gene [33].

Practically nothing is known about two other resistance crises: multi-resistant Neisseria gonorrhoeae, and Clostridioides difficile. These organisms are seldom cultured in Mexico.

\section{Resistance in non-clinical isolates}

If data on resistance rates among clinically relevant bacteria is scarce and unreliable, much less is known about bacteria in animals and the environment. A recent report on global resistance rates in animals and food products identified a potential hotspot in "the areas surrounding Mexico City". The study analyzed data on E. coli, Campylobacter spp., non-typhoidal Salmonella spp. and Staphylococcus aureus [34]. In a study of the 
fecal microbiota of forest wildlife (howler and spider monkeys, tapirs and felids) showed that the vast majority of samples (76-100\%) contained at least one resistant organism, and the average number of resistance phenotypes per isolate was 1.7-2.1; samples collected at a distance $\leq 2.5 \mathrm{~km}$ from a human settlement had significantly higher number of resistant isolates per sample, and number of resistance phenotypes per sample, than those collected farther away. A few organisms from this study were resistant to ciprofloxacin, and/or produced ESBLs, and/or carried class-1 integrons [35]. Finally, during a recent surveillance of resistance in wastewater from Mexico City, several E. coli isolates were found to be resistant to carbapenems, and a metallo-beta-lactamase, NDM5 , not reported before in clinical isolates, was found to be the cause (K. Lüneberg et al., submitted). The very same wastewater system was previously reported to contain azithromycin, ciprofloxacin, enrofloxacin, lincomycin, ofloxacin, sulfamethoxazole, trimethoprim, tetracyclines, and the disinfectant triclosan, many of them in the single-digit $\mu \mathrm{g} / \mathrm{L}$ range [36].

\section{Resistance without borders}

Travel from rich to poor countries, seeking cheaper or elective medical treatment, is a common and growing trend; this is one variety of medical tourism, a practice done by around 20 million patients worldwide each year. This has been linked to the spread of dangerous resistance traits, such as the NDM-1 [37]. Mexican cities, especially those close to the US border, have a flourishing medical tourism industry, that received around 1.5 million patients and 3.5 billion dollars in 2017 [38]. The acquisition of commensal resistant bacteria in the microbiota, a risk carried by all kinds of international tourism, is compounded by the potential acquisition of multi-resistant pathogens gathered during a stay at a healthcare facility. While not dealing with deliberate medical tourism, a recent report on the mobilization of resistant organisms from Mexico to the US in trauma patients illustrates the point. Trauma patients that were initially hospitalized in Mexico and then transferred to hospitals in San Diego, CA, were more frequently infected, especially by gram-negative pathogens; and more frequently displayed dangerous resistance phenotypes: ESBL production among enteric bacteria, methicillin-resistance in $S$. aureus (MRSA), and multi-resistance among $P$. aeruginosa and Acinetobacter baumannii. The gram-negatives were significantly less susceptible to ceftriaxone, cefepime, piperacillin-tazobactam and gentamicin, if they were isolated from patients initially treated in Mexico [39]. In this way, what happens in Mexico, does not necessarily stays in Mexico. This is yet another reminder that antibiotic resistance is not limited by political borders.

\section{Ethics}

The ethics of antibiotic usage, and of the measures intended to curtail resistance, have been discussed elsewhere [40]. A particular ethical conundrum, the expenditure of multi-billions of dollars (and the imprisonment of millions of persons, and the killing of just as many) in the worldwide "war on drugs", that criminalizes recreational drugs, whose victims are the users themselves; while neglecting the abuse of antibiotics [41], that is fuelling resistance that currently kills 700,000 people yearly -mostly not those abusing antibiotics, is of particular concern for Mexico. On 2006 , the country was dragged into an all-out war on drugs which, by 2016 , consumed US $\$ 2.7$ billion, just in US "aid" towards this goal. This, in addition to more that 200,000 homicides, 37,000 disappearances, and 345,000 people displaced because of conflict and violence [42], not because of drugs, but because of the "war on drugs". Is it ethical to keep "wasting resources trying to fight an unwinnable and morally dubious war against recreational drugs" instead of directing such resources towards the actual public health threat posed by antibiotic resistance?

\section{Concluding remarks}

Mexico's representation at the United Nations was tasked with writing the outcome document of the General Assembly high-level meeting on antimicrobial resistance, of Sept. 21, 2016. Yet it took nearly two years for the Mexican government to publish a National Action Strategy against Antimicrobial Resistance [43], a list of good wishes and things that "need to be done", but without specific goals and timetables. Most importantly, the document clearly states that no additional funds would be devoted to any of the proposed actions. Two further years later, none of the functions of the UN Coordinating Mechanism (advocacy, monitoring and evaluation, resource mobilization and multisectoral action coordination; [44]) have been set into motion in Mexico. With the COVID-19 crisis stressing the budget and healthcare capabilities of the country, it is unlikely that measures against antibiotic resistance get the attention and funding needed. As Mexico gets even poorer, the use of antibiotics may shrink even more, which would be an apparently right outcome, but of the wrong causes. Less 
antibiotic usage due to poverty instead of prudence, would not help to control resistance.

\section{References}

1. Amábile-Cuevas CF (2010) Antibiotic resistance in Mexico: a brief overview of the current status and its causes. J Infect Dev Ctries 4: 126-131. doi: 10.3855/jidc.427.

2. World Health Organization (WHO) (2017) Primary health care systems (PRIMASYS), case study from Mexico. Available: https://www.who.int/alliance-

hpsr/projects/alliancehpsr_mexicoprimasys.pdf?ua=1.

Accessed: 19 April 2021.

3. CONEVAL (2014) Multidimensional measurement of poverty in Mexico: an economic wellbeing and social rights approach. Mexico City: National Council for the Evaluation of Social Development Policy. Available: https://www.coneval.org.mx/InformesPublicaciones/FolletosI nstitucionales/Documents/Multidimensional-Measurementof-poverty-in-Mexico.pdf. Accessed: 19 April 2021 Report in Spanish].

4. Wirtz VJ, Dreser A, Gonzales R (2010) Trends in antibiotic utilization in eight Latin American countries, 1997-2007. Rev Panam Salud Publica 27: 219-225.

5. Van Boeckel TP, Gandra S, Ashok A, Caudron Q, Grenfell BT, Levin SA, Laxminarayan R (2014) Global antibiotic consumption 2000 to 2010: an analysis of national pharmaceutical sales data. Lancet Infect Dis 14: 742-750.

6. Klein EY, Van Boeckel TP, Martinez EM, Pant S, Gandra S, Levin SA, Goossens H, Laxminarayan R (2018) Global increase and geographic convergence in antibiotic consumption between 2000 and 2015. Proc Natl Acad Sci USA 115: E3463-E3470.

7. Toscano Velasco MA (2010) Antibiotics: everyone's responsability. El Universal, Mexico City. Available: https://archivo.eluniversal.com.mx/editoriales/49616.html. Accessed: 19 April 2021 [Article in Spanish].

8. Zaidi MB, Dreser A, Figueroa IM (2015) A collaborative initiative for the containment of antimicrobial resistance in Mexico. Zoonoses Pub Health 62: 52-57.

9. Santa-Ana-Tellez Y, Mantel-Teeuwisse AK, Dreser A, Leufkens HGM, Wirtz VJ (2013) Impact of over-the-counter restrictions on antibiotic consumption in Brazil and Mexico. PLoS One 8: e75550.

10. Rodriguez CA, Agudelo M, Zuluaga AF, Vesga O (2015) Impact on resistance of the use of therapeutically equivalent generics: the case of ciprofloxacin. Antimicrob Agents Chemother 59: 53-58.

11. Rodriguez CA, Agudelo M, Aguilar YA, Zuluaga AF, Vesga O (2016) Impact on bacterial resistance of therapeutically nonequivalent generics: the case of piperacillin-tazobactam. PLoS One 11: e0155806.

12. Jensen US, Muller A, Brandt CT, Frimodt-Møller N, Hammerun AM, Monnet DL, DANRES study group (2010) Effect of generics on price and consumption of ciprofloxacin in primary healthcare: the relationship to increasing resistance. J. Antimicrob Chemother. 65: 1286-1291.

13. Eban K (2013) Dirty medicine. Fortune May Available: https://fortune.com/2013/05/15/dirty-medicine/. Accessed: 19 April 2021.

14. Maron DF, Smith TJS, Nachman KE (2013) Restrictions on antimicrobial use in food animal production: an international regulatory and economic survey. Globb Health 9: 48.
15. Van Boeckel TP, Brower C, Gilbert M, Grenfell BT, Levin SA, Robinson TP, Teillant A, Laxminarayan R (2015) Global trends in antimicrobial use in food animals. Proc Natl Acad Sci USA 112: 5649-5654.

16. Amábile-Cuevas CF (2016) Antibiotics and antibiotic resistance in the environment. Leiden: CRC Press/Balkema. pp. 47-71.

17. Collignon P, Athukorala P, Senanayake S, Khan F (2015) Antimicrobial resistance: the major contribution of poor governance and corruption to this growing problem. PLoS One 10: e0116746.

18. Arredondo-García JL, Amábile-Cuevas CF (2008). J Infect Dev Ctries 2: 350-353. doi: 10.3855/jidc. 195.

19. Molina-López J, Aparicio-Ozores G, Ribas-Aparicio RM, Gavilanes-Parra S, Chávez-Berrocal ME, Hernández-Castro R, Manjarrez-Hernández HA (2011) Drug resistance, serotypes, and phylogenetic groups among uropahogenic Escherichia coli including O25-ST131 in Mexico City. J Infect Dev Ctries 5: 840-849. doi: 10.3855/jidc. 1703 .

20. Morales-Espinosa R, Hernández-Castro $R$, Delgado $G$, Mendez JL, Navarro A, Manjarrez A, Cravioto A (2016) UPEC strain characterization isolated from Mexican patients with recurrent urinary infections. J Infect Dev Ctries 10: 317-328. doi: $10.3855 /$ jidc. 6652 .

21. Lagunas-Rangel FA (2018) Antimicrobial susceptibility profiles of bacteria causing urinary tract infections in Mexico: single-centre experience with 10 years of results. J Global Antimicrob Resist 14: 90-94.

22. González-Olvera EM, Pérez-Morales R, González-Zamora A, Castro-Escarpulli G, Palma-Martínez I, Alba-Romero JJ (2019) Antibiotic resistance, virulence factors and genotyping of Pseudomonas aeruginosa in public hospitals of northeastern Mexico. J Infect Dev Ctries 13: 374-383. doi: 10.3855/jidc. 10953 .

23. Morfin-Otero R, Rodriguez Noriega E, Dowzicky MJ (2015) Antimicrobial susceptibility trends among gram-positive and gram-negative clinical isolates collected between 2005 and 2012 in Mexico: ersults from the Tigecycline Evaluation and Surveillance Trial. Ann Clin Microbiol Antimicrob 14: 53.

24. Morfin-Otero R, Tinoco-Favila JC, Sader HS, SalcidoGutierrez L, Perez-Gomez HR, Gonzalez-Diaz E, Petersen L, Rodriguez-Noriega E (2012) Resistance trends in gramnegative bacteria: surveillance results from two Mexican hospitals, 2005-2010. BMC Res Notes 5: 277.

25. Stone GG, Ponce-de-León A (2020) In vitro activity of ceftazidime/avibactam and comparators against Gramnegative bacterial isolates collected from Latin American Centres between 2015 and 2017. J Antimicrob Chemother 75: 1859-1873.

26. Rosales-Reyes R, Rodríguez-Alvarado M, Lezana-Fernández JL, Sánchez-Lozano JY, Gayosso-Vázquez C, Jarillo-Quijada MD, Toledano-Tableros JE, Arredondo-Mercado MJ, Alcántar-Curiel MD, Lincopan N, Vidal JE, Lascurain R, Valvano MA, Santos-Preciado JI (2020) Pseudomonas aeruginosa isolates from a cohort of Mexican children with cystic fibrosis show adaptation to a chronic phenotype. Pediatr Infect Dis J 39: 899-906.

27. Garza-González E, Morfín-Otero R, Mendoza-Olazarán S, Bocanegra-Ibarias P, Flores-Treviño S, Rodríguez-Noriega E, Ponce-de-León A, Sanchez-Francia D, Franco-Cendejas R, Arroyo-Escalante S, Velázquez-Acosta C, Rojas-Larios F, Quintanilla LJ, Maldonado-Anicacio JY, Martínez-Miranda R, Ostos-Cantú HL, Gomez-Choel A, Jaime-Sanchez JL, Avilés- 
Benítez LK, Feliciano-Guzmán JM, Peña-López CD, CouohMay CA, Molina-Jaimes A, Vázquez-Narvaez EG, RincónZuno J, Rivera-Garay R, Galindo-Espinoza A, MartínezRamirez A, Mora JP, Corte-Rojas RE, López-Ovilla I, Monroy-Colin VA, Barajas-Magallón JM, Morales-De-laPeña CT, Aguirre-Burciaga E, Coronado-Ramírez M, RosalesGarcía AA, Ayala-Tarín MJ, Sida-Rodríguez S, Pérez-Vega BA, Navarro-Rodríguez A, Juárez-Velázquez GE, CetinaUmaña CM, Mena-Ramírez JP, Canizales-Oviedo J, MorenoMéndez MI, Romero-Romero D, Arévalo-Mejía A, CobosCanul DI, Aguilar-Orozco G, Silva-Sanchez J, Camacho-Ortiz A (2019) A snapshot of antimicrobial resistance in Mexico. Results from 47 centers from 20 states during a six-month period. PLoS One 14: e0209865.

28. Yong D, Toleman MA, Giske CG, Cho HS, Sundman K, Lee K, Walsh TR (2009) Characterization of a new metallo- $\beta$ lactamase gene, bla $a_{\mathrm{NDM}-1}$, and a novel erythromycin esterase gene carried on a unique genetic structure in Klebsiella pneumoniae sequence type 14 from India. Antimicrob Agents Chemother 53: 5046-5054.

29. Barrios H, Garza-Ramos U, Reyna-Flores F, Sanchez-Perez A, Rojas-Moreno T, Garza-González E, Llaca-Díaz JM, Camacho-Ortiz A, Guzmán-López S, Silva-Sanchez J (2013) Isolation of carbapenem-resistant NDM-1-positive Providencia rettgeri in Mexico. J Antimicrob Chemother 68: 1934-1936.

30. Torres-González P, Bobadilla-Del Valle M, Tovar-Calderón E, Leal-Vega F, Hernández-Cruz A, Martínez-Gamboa A, Niembro-Ortega MD, Sifuentes-Osornio J, Ponce-de-León A (2015) Outbreak caused by Enterobacteriaceae harboring NDM- 1 metallo- $\beta$-lactamase carried in an IncFII plasmid in a tertiary care hospital in Mexico City. Antimicrob Agents Chemother 59: 7080-7083.

31. Liu YY, Wang Y, Walsh TR, Yi LX, Zhang R, Spencer J, Doi Y, Tian G, Dong B, Huang X, Yu LF, Gu D, Ren H, Chen X, Lv L, He D, Zhou H, Liang Z, Liu JH, Shen J (2016) Emergence of plasmid-mediated colistin resistance mechanism MCR-1 in animals and human beings in China: a microbiological and molecular biological study. Lancet Infect Dis 16: 161-168.

32. Garza-Ramos U, Tamayo-Legorreta E, Arellano-Quintanilla DM, Rodriguez-Medina N, Silva-Sanchez J, Catalan-Najera J, Rocha-Martínez MK, Bravo-Díaz MA, Alpuche-Aranda C (2018) Draft genome sequence of a multidrug- and colistinresistant $m c r$-1-producing Escherichia coli isolate from a swine farm in Mexico. Genome Announc 6: e00102-18.

33. Merida-Vieyra J, De Colsa-Ranero A, Arzate-Barbosa P, Arias-de la Garza E, Méndez-Tenorio A, Murcia-Garzón J, Aquino-Andrade A (2019) First clinical isolate of Escherichia coli harboring mcr-1 gene in Mexico. PLoS One 14: e0214658.

34. Van Boeckel TP, Pires J, Silvester R, Zhao C, Song J, Criscuolo NG, Gilbert M, Bonhoeffer S, Laxminarayan R (2019) Global trends in antimicrobial resistance in animals in low- and middle-income countries. Science 365: eaaw1944.

35. Cristóbal-Azkarate J, Dunn JC, Day JMW, Amábile-Cuevas CF (2014) Resistance to antibiotics of clinical relevance in the fecal microbiota of Mexican wildlife. PLoS One 9: e107719.

36. Lesser LE, Mora A, Moreau C, Mahlknecht J, HernándezAntonio A, Ramírez AI, Barrios-Piña H (2018) Survey of 218 organic contaminants in groundwater derived from the world's largest untreated wastewater irrigation system: Mezquital Valley, Mexico. Chemosphere 198: 510-521.
37. Kumarasamy KK, Toleman MA, Walsh TR, Bagaria J, Butt F, Balakrishnan R, Chaudhary U, Doumith M, Giske CG, Irfan S, Krishnan P, Kumar AV, Maharjan S, Mushtaq S, Noorie T, Paterson DL, Pearson A, Perry C, Pike R, Rao B, Ray U, Sarma JB, Sharma M, Sheridan E, Thirunarayan MA, Turton J, Upadhyay S, Warner M, Welfare W, Livermore DM, Woodford N (2010) Emergence of a new antibiotic resistance mechanism in India, Pakistan, and the UK: a molecular, biological, and epidemiological study. Lancet Infect Dis 10: 597-602.

38. Gámez A (2019) Mexico, an attactive market for medical tourism. El Universal, Mexico City. Available: https://www.eluniversal.com.mx/cartera/negocios/mexicomercado-atractivo-para-el-turismo-medico. Accessed: 19 April 2021. [Article in Spanish].

39. Berndtson AE, Bricker-Ford R, Box K, Madsen GZ, Malany L, Smith AM, Costantini TW, Coimbra R (2019) Cross-border antibiotic resistance patterns in trauma patients. Surgery 166 : 109-115.

40. Anomaly J (2017) Ethics, antibiotics, and public policy. Georgetown J. Law Pub. Policy Available: https://philpapers.org/archive/ANOEAA.pdf. Accessed: 11 April 2021.

41. Anomaly J (2013) Collective action and individual chioce: rethinking how we regulate narcotics and antibiotics. J Med Ethics 39: 721.

42. Piaggio A, Vidwans P (2019) The cost and consequences of the war on drugs. New York: Human Rights Foundation. Available: fileserver.idpc.net/library/the-cost-andconsequence.pdf. Accessed: 11 April 2021.

43. General Health Council (2018) Agreement declaring the mandatory nature of the National Strategy for action against Antimicrobial Resistance. Official Gazette of the Federation 06/05/2018. Available: http://dof.gob.mx/nota_detalle.php?codigo $=5525043 \&$ fecha $=$ 05/06/2018. Accessed: 19 April 2021. [Article in Spanish]

44. Laxminarayan R, Amábile-Cuevas CF, Cars O, Evans T, Heymann DL, Hoffman S, Holmes A, Mendelson M, Sridhar D, Woolhouse M, Røttingen JA (2016) UN High-Level Meeting on antimicrobials -what do we need? Lancet 388: 218220.

45. Echaniz-Aviles G, Garza-González E, Román-Mancha AL, Morfín-Otero R, Rodríguez-Noriega E, Ayala-Gaytán JJ, Guajardo-Lara CE, Soto-Noguerón A, Carnalla-Barajas MN, Camacho-Ortiz A (2019) Clinical and microbiological characteristics of community-acquired pneumonia associated with Streptococcus pneumoniae in adult patients. Rev Argent Microbiol 51: 234-240.

46. Flores-Treviño S, Rodríguez-Noriega E, Garza-González E, González-Díaz E, Esparza-Ahumada S, Escobedo-Sánchez R, Pérez-Gómez HR, León-Garnica G, Morfín-Otero R (2019) Clinical predictors of drug-resustant tuberculosis in Mexico. PLoS One 14: e0220946.

\section{Corresponding author}

Carlos F. Amábile-Cuevas, D.Sc.

Fundación Lusara, Apartado postal 8-895, 08231, Mexico City, Mexico

Phone: (52-55)52195855.

E-mail: carlos.amabile@lusara.org

Conflict of interests: No conflict of interests is declared. 